\title{
Antioxidant/anti-inflammatory activities and chemical composition of extracts from the mushroom Trametes versicolor
}

\author{
Masumi Kamiyama $^{1}$, Masahiro Horiuchi ${ }^{2}$, Katsumi Umano ${ }^{2}$, Kazuo Kondo ${ }^{3}$, Yuzuru Otsuka ${ }^{3}$, \\ Takayuki Shibamoto \\ ${ }^{1}$ Department of Environmental Toxicology, University of California, Davis, CA 95616, USA \\ ${ }^{2}$ Takata Koryo Co. Ltd., 7-22-2 Tsukaguchihonmachi, Amagasaki-Shi, Hyogo, 661-0001 Japan \\ ${ }^{3}$ Institute of Environmental Science for Human Life, Ochanomizu University, Bunkyo-ku, Tokyo, 112-8610 Japan
}

\author{
Email address: \\ tshibamoto@ucdavis.edu (T. Shibamoto)
}

\section{To cite this article:}

Masumi Kamiyama, Masahiro Horiuchi, Katsumi Umano, Kazuo Kondo, Yuzuru Otsuka, Takayuki Shibamoto. Antioxidant/AntiInflammatory Activities and Chemical Composition of Extracts from the Mushroom Trametes Versicolor, International Journal of Nutrition and Food Sciences. Vol. 2, No. 2, 2013, pp. 85-91. doi: 10.11648/j.ijnfs.20130202.19

\begin{abstract}
The mushroom, Trametes versicolor is commonly used as a traditional Chinese medicine and is known to exhibit various biological activities. However, its antioxidant activity has remained unknown. In the present study, various extracts obtained from the Trametes versicolor mushroom were examined for antioxidant and anti-inflammatory activities. Among the extracts obtained with Soxhlet extraction, the extract from acetone exhibited the highest antioxidant activity (50.9\%), followed by the extracts from methanol (33.9\%), n-hexane (29.5\%), and chloroform (15.2\%) at the level of 500 $\mu \mathrm{g} / \mathrm{mL}$. This acetone fraction displayed a dose-dependent anti-inflammatory activity or lipoxygenase inhibitory activity by $76.4 \%$ at $500 \mu \mathrm{g} / \mathrm{mL}, 55.6 \%$ at $200 \mu \mathrm{g} / \mathrm{mL}$, and $37.0 \%$ at $100 \mu \mathrm{g} / \mathrm{mL}$. Among a total of 76 compounds identified in this acetone extract, hexadecanoic acid was the largest component $(18.11 \mathrm{mg} / \mathrm{kg})$, followed by 5 -hydroxy-2-pentanone (17.33 $\mathrm{mg} / \mathrm{kg})$, lactic acid $(3.25 \mathrm{mg} / \mathrm{kg})$, and acetic acid $(3.21 \mathrm{mg} / \mathrm{kg})$. The following possible principles of antioxidant activity were identified: furfural $(1.48 \mathrm{mg} / \mathrm{kg}), \gamma$-butyrolactone $(0.51 \mathrm{mg} / \mathrm{kg})$, furfuryl alcohol $(0.49 \mathrm{mg} / \mathrm{kg})$, 2-methoxy-4vinylphenol $(0.49 \mathrm{mg} / \mathrm{kg})$, and 2,6-dimetoxy-4-vinylphenol $(0.33 \mathrm{mg} / \mathrm{kg})$, and benzaldehyde $(0.15 \mathrm{mg} / \mathrm{kg})$.
\end{abstract}

Keywords: Trametes Versicolor Mushroom, Medicinal Plants, Antioxidant, Anti-Inflammatory, Lipoxygenase Inhibitor

\section{Introduction}

Edible mushrooms have been consumed since ancient times and about 200 species are consumed in the world today [1]. In 2008, the world production total of edible mushroom was over one million tons, wherein China produced approximately $50 \%$ of global total productions [2]. Currently, edible mushrooms are either commercially available in grocery stores or found in the wild. Mushrooms are rich in proteins and compounds with various biological activities including antioxidant [3], anti-tumor [4], antimicrobial [5], anti-hyperglycemic [6], anticholinesterase [7], immunostimulant [8], and anti-mutagenic [9] properties. Therefore, mushrooms are ideal health foods [10]. Also, many mushrooms have been used as folk medicine since the eras of Ancient China, Rome, and Greece [11].
Trametes versicolor is a Chinese medicinal mushroom known to possess a wide range of biological activities including immune-enhancing activity [12], antitumor [13], and antiviral effects [14]. A prophylactic bioactive of the mushroom extract, known as PSK, has been demonstrated to be effective against carcinogenesis [15]. Derived from the extract of T. versicolor mycelia, PSK (Krestin; PSK) is a protein-bound polysaccharide approved for use in cancer treatment by the Japanese Ministry of Health and Welfare in 1977 [16]. This was the first polysaccharide antitumor drug approved by the regulatory agency. Although T. versicolor has been known to possess various biological effects, its antioxidant activity is not well established. It is important to know about antioxidant activity in order to elucidate the medicinal mechanisms of biological effects because most diseases are associated with oxidative damage [17]. Free radical and oxygen reactive species affect the mechanisms of many diseases including diabetes, atherosclerosis, 
aging, neurodegenerative disorders, as well as cancer [18]. Therefore, some antioxidants found in natural plants may be effective in combating these diseases [19].

In the present study, the antioxidant/anti-inflammatory activities and chemical components of extracts from mushroom, T. versicolor was investigated to learn more about their healthful effects on humans.

\section{Materials and Methods}

\subsection{Chemicals and Reagents}

n-Hexane, chloroform, acetone, methanol, water (HPLCgrade), sodium dodecyl sulfate (SDS), hydrogen peroxide, and butylated hydroxytoluene (BHT) were purchased from Fisher Scientific Co. (Rochester, NY, USA). Dichloromethane, cod liver oil, ferrous chloride tetrahydrate $\left(\mathrm{FeCl}_{2} \bullet 4 \mathrm{H}_{2} \mathrm{O}\right)$, N-methylhydrazine, 1-methylpyrazole (1MP), 2-methylpyrazine, tris(hydroxymethyl)aminomethane (Tris), tris(hydroxymethyl)aminomethane hydrochloride, nordihydroguaretic acid (NDGA), 1,1-Diphenyl-2picrylhydrazyl (DPPH) were bought from Sigma-Aldrich Chemical Co. (St. Louis, MO, USA). A Lipoxygenase Inhibitor Screening Assay (LISA) kit ${ }^{\circledR}$ was purchased from Cayman Chemical Co. (Portland, OR, USA). Standard volatile chemicals for analysis of the acetone extract were a gift from TAKATA KORYO Co., Ltd., (Hyogo, Japan).

\subsection{Plant Samples}

T. versicolor mushrooms were purchased from Marue pharmacy (Tokyo, Japan). The T. versicolor mushroom used in this study was harvested in Nagano prefecture in Japan in 2010.

\subsection{Sample Preparations}

Samples were prepared for analysis of components and antioxidant tests [20].

\subsubsection{Steam Distillation}

The fruit body of $\mathrm{T}$. versicolor was ground into a fine powder using a blender. Samples of the resultant powder $(50 \mathrm{~g})$ were placed in $2 \mathrm{~L}$ two-necked flasks with $1 \mathrm{~L}$ water. Each sample was steam distilled at $55^{\circ} \mathrm{C}$ and $95 \mathrm{mmHg}$ for $7 \mathrm{~h}$. The steam distillate $(800 \mathrm{~mL})$ was extracted with 100 $\mathrm{mL}$ dichloromethane for $6 \mathrm{~h}$ using a liquid-liquid continuous extractor. The extract was dried over anhydrous sodium sulfate for $12 \mathrm{~h}$. After removal of the sodium sulfate, the extract was condensed to approximately $2 \mathrm{~mL}$ using a rotary evaporator. The extract was further condensed under a purified nitrogen stream to $575 \mathrm{mg}$. This sample was tested for antioxidant activity by an MA/GC assay, DPPH assay, and an anti-inflammatory lipoxygenase assay.

\subsubsection{Column Chromatography of Residual Aqueous Solution}

The residual aqueous solution $(800 \mathrm{~mL})$ after dichloromethane extraction was condensed to $5 \mathrm{~mL}$ and placed in a glass column $(30 \mathrm{~cm} \times 2.5 \mathrm{~cm}$ i.d.) packed with Amberlite XAD-2 resin (Sigma-Aldrich Chemical Co., St. Louis, MO, USA). The sample was eluted sequentially with $100 \mathrm{~mL}$ each of water and acetone. The water and acetone fractions were then condensed to $2 \mathrm{~mL}$ and subsequently reduced to $14.7 \mathrm{mg}$ and $10.3 \mathrm{mg}$, respectively, using a purified nitrogen stream. These samples were tested for antioxidant activity with the MA/GC assay and the anti-inflammatory assay.

\subsubsection{Soxhlet Extraction of Mushroom Powder Sample}

A powder sample $(50 \mathrm{~g})$ was extracted sequentially with $250 \mathrm{~mL}$ each of n-hexane, chloroform, acetone, and methanol using a Soxhlet extractor. The extracts were condensed using a rotary evaporator to $2 \mathrm{~mL}$ and then condensed further with a purified nitrogen stream to $46.9 \mathrm{mg}$ for the nhexane extract, $242.4 \mathrm{mg}$ for the chloroform extract, 200.9 $\mathrm{mg}$ for the acetone extract, and $468.0 \mathrm{mg}$ for the methanol extract. These samples were tested for antioxidant activity with MA/GC and DPPH assays and anti-inflammatory (lipoxygenase) assay.

\subsection{Antioxidant Activity Tests}

The antioxidant activities of samples were tested according to previously reported methods [17]. The levels of antioxidant activity were calculated by a previously reported method [21]. All experiments were repeated three times.

\subsubsection{Malonaldehyde/Gas Chromatography (MA/GC) Assay}

MA/GC assays were performed according to a previously reported method [17]. Briefly, a test sample was added to an assay solution $(5 \mathrm{~mL})$ containing $10 \mu \mathrm{L}$ cod liver oil in a $20 \mathrm{~mL}$ test tube. After a sample was incubated at $37^{\circ} \mathrm{C}$ for $18 \mathrm{~h}$, the MA formed in the sample was analyzed as 1methylpyrazole derivative by an Agilent Technologies model $6890 \mathrm{~N}$ GC equipped with a $30 \mathrm{~m} \times 0.25 \mathrm{~mm}$ i.d. (df $=0.25 \mu \mathrm{m}$ ) DB-wax fused-silica capillary column (Agilent Technologies Inc., Santa Clara, CA, USA) and a nitrogenphosphorus detector (NPD). The GC oven temperature was programmed to rise from $70^{\circ} \mathrm{C}$ to $120{ }^{\circ} \mathrm{C}$ at $4{ }^{\circ} \mathrm{C} / \mathrm{min}$. The injector and detector temperatures were $260^{\circ} \mathrm{C}$ and $280{ }^{\circ} \mathrm{C}$, respectively. The helium carrier gas flow rate was 1.4 $\mathrm{mL} / \mathrm{min}$. The entire assay was performed in duplicate.

\subsubsection{DPPH Radical Scavenging Assay}

The DPPH radical scavenging assay on samples from Soxhlet extraction was conducted according to a previously reported method [17]. Briefly, a mixture containing a test sample and DPPH was incubated at room temperature for $30 \mathrm{~min}$ and then the absorbance at $517 \mathrm{~nm}$ was measured with a Hewlett-Packard 8452A diode array spectrophotometer (Hewlett-Packard Co., Palo Alto, CA, USA).

\subsection{Anti-inflammatory Test}

An anti-inflammatory test was performed on samples prepared by steam distillation and Soxhlet extraction using 
the LISA kit (Cayman Chemical Co., Ann Arbor, MI, USA) as previously described [21]. Briefly, A 15-LOX lipoxygenase enzyme solution $(90 \mu \mathrm{L})$ and a testing sample $(10 \mu \mathrm{L})$ were placed in the testing well. The reaction was initiated by adding a $10 \mu \mathrm{L}$ of arachidonic acid substrate solution to a testing sample well. All testing wells were then covered and placed on a shaker (Bellco Biotechnology, Vineland, NJ, USA) for $5 \mathrm{~min}$. Chromogen $(100 \mu \mathrm{L})$ was added to the reaction wells to stop the enzyme catalysis and prevent further development of the reaction. The level of hydroperoxides (HP) produced by 15 -LOX from arachidonic acid were measured by the UV absorbance at $490 \mathrm{~nm}$.

\subsection{Identify the Chemical Components of Acetone Ex- tract Using GC/MS}

The acetone extract prepared by Soxhlet extraction was analyzed for its components using GC/MS because antioxidant and anti-inflammatory activities of this extract exhibited the highest levels of antioxidants and antiinflammatories. The chemical components in the acetone extract were identified by comparison with the Kovat's gas chromatographic retention index and mass spectrometric pattern of each component and those of authentic compounds. An Agilent model 6890 GC interfaced to an Agilent 5973 Network Mass Selective Detector (Foster City, CA, USA) was used for mass spectral identification of the $\mathrm{GC}$ components at MS ionization voltage of $70 \mathrm{eV}$. A $60 \mathrm{~m}$ x $0.25 \mathrm{~mm}$ i.d. ( df $=0.25 \mu \mathrm{m}$ ) DB-WAX bonded phase fused silica capillary column ( $\mathrm{J} \& \mathrm{~W}$ Scientific, Folsom, CA, USA) was used for GC. The linear velocity of the helium carrier gas was $30 \mathrm{~cm} / \mathrm{sec}$. The injector and the detector temperatures were $250^{\circ} \mathrm{C}$. The oven temperature was programmed to rise from 40 to $200^{\circ} \mathrm{C}$ at $2^{\circ} \mathrm{C} / \mathrm{min}$. The identification of chemicals was also confirmed with the MS library of the NIST AMDIS version 2.1 software.

\subsection{Statistical Processing}

Results are expressed as the mean \pm SD $(n=3)$. Data were analyzed by one-way ANOVA, followed by Dunnett's test for separate comparisons with the control group. Differences were considered significant at a $\mathrm{P}$ value of $<0.05$.

\section{Results and Discussion}

\subsection{Antioxidant Activities of Samples}

Figure 1 shows the results of MA/GC assay on the samples prepared by steam distillation. The extracts were tested at the level of $500 \mu \mathrm{g} / \mathrm{mL}$. A standard antioxidant, BHT was examined at $100 \mu \mathrm{g} / \mathrm{mL}$ and exhibited high inhibitory effect to MA production $(99.1 \pm 0.2 \%)$, indicating that the method used in this study was valid. Among the samples tested, the acetone fraction showed the highest antioxidant activity $(52.0 \pm 2.2 \%)$, followed by the dichloromethane extract $(7.0 \pm 11.0 \%)$ and the water fraction $(5.3 \pm 8.5 \%)$.

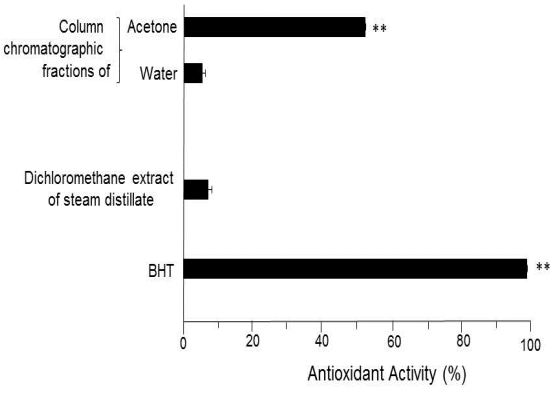

Figure 1. The results of the $M A / G C$ assay on samples prepared with steam distillation. Values are means $\pm S D(n=3)$. *: $p<0.05$ 、**: $p<$ 0.01 .

Figure 2 shows the results of the MA/GC assays of the samples prepared by Soxhlet extraction. The amounts of the extracts collected from each solvent fraction after removal of the solvent were $46.9 \mathrm{mg}$ from n-hexane, 242.4 $\mathrm{mg}$ from chloroform, $200.9 \mathrm{mg}$ from acetone, and 468.0 $\mathrm{mg}$ from methanol. Three concentrations of each extract, 100,200 , and $500 \mu \mathrm{g} / \mathrm{mL}$ were tested. BHT exhibited 96.6 $\pm 0.19 \%$ antioxidant activity at the level of $100 \mu \mathrm{g} / \mathrm{mL}$, indicating that this assay is valid. The acetone extract showed moderate antioxidant activity with a dose response ranging from $50.9 \pm 5.2 \%(500 \mu \mathrm{g} / \mathrm{mL})$ to $32.5 \pm 0.5 \%$ $(100 \mu \mathrm{g} / \mathrm{mL})$. Also, the methanol and hexane extracts exhibited moderate activities of $33.9 \pm 0.4 \%$ and $29.5 \pm 6.0 \%$ at the levels of $500 \mu \mathrm{g} / \mathrm{mL}$, respectively. Both extracts also showed dose responses. The chloroform extract exhibited slight antioxidant activity without dose response. These results suggest that antioxidant principles are polar compounds.

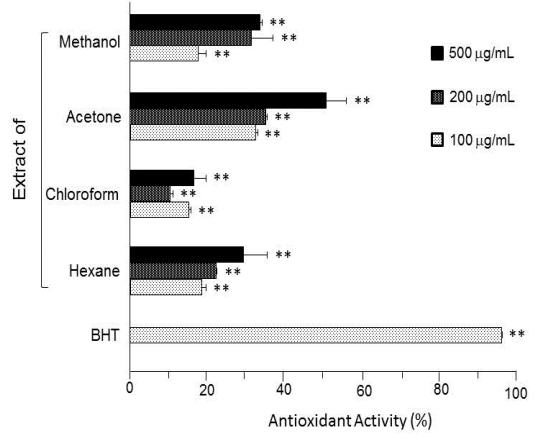

Figure 2. The results of the $M A / G C$ assay on samples prepared by Soxhlet extraction. Values are means $\pm S D(n=3)$. *: $p<0.05$ 、**: $p<0.01$.

The antioxidant activities of the samples from Soxhlet extraction were also tested by DPPH assays. Figure 3 shows the results of the DPPH assay on the samples from Soxhlet extraction. BHT exhibited $89.2 \pm 5.7 \%$ antioxidant activity. All extracts showed dose response antioxidant activity. Acetone extract exhibited the highest antioxidant activity at $54.9 \pm 0.1 \%$, followed by the methanol extract at $40.0 \pm 0.2 \%$ at the level of $500 \mu \mathrm{g} / \mathrm{mL}$. The values obtained from the chloroform and hexane extracts were relatively low but they also showed appreciable antioxidant activities. 


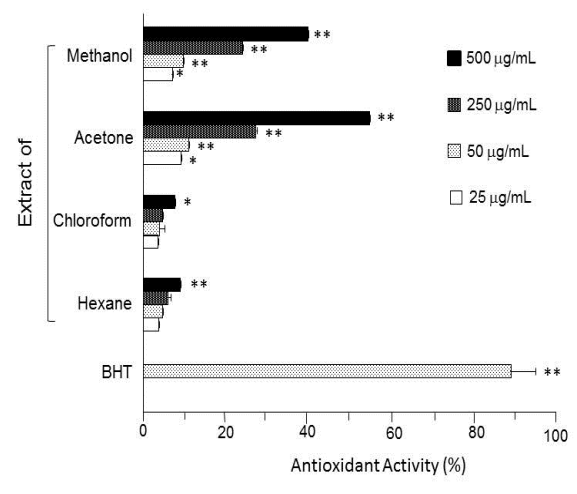

Figure 3. The results of the DPPH assay on samples from Soxhlet extraction. Values are means $\pm S D(n=3)$. *: $p<0.05$ 、**: $p<0.01$

A previous study demonstrated that methanol extracts of black and red ear mushrooms exhibited $100 \%$ antioxidant activity at the level of $1.0 \mathrm{mg} / \mathrm{mL}$ by DPPH assay [22]. Also, ethanol extracts from mushroom species Phellinus Quél and their isolated fractions exhibited antioxidant activity and protected PC 2 cells against oxidative damage [23]. Another study reported that ethanolic extracts from the mushroom Coprinus comatus possessed higher antioxidant activity $(47.0 \%$ at $20 \mu \mathrm{g} / \mathrm{mL})$ than hot water extract [24]. A peptide obtained from another fermented mushroom (Ganoderma lucidum) showed inhibitory activities toward lipid peroxidation and lipoxigenase activity, which has been used to examine anti-inflammatory activity [25].

\subsection{Anti-inflammatory Activity of Samples}

This anti-inflammatory assay involves the measurement of inhibitory activity of samples toward lipoxygenase formation in the test solution.

Figure 4 shows the results of the anti-inflammatory assay on the samples prepared by steam distillation. Values are mean $\pm \mathrm{SD}(\mathrm{n}=3)$. A standard lipoxygenase inhibitory chemical, NDGA, inhibited 15-lipoxygenase activity by 66 . $7 \pm 3.5 \%$ at $100 \mu \mathrm{g} / \mathrm{mL}$. The dichloromethane extract exhibited the greatest lipoxygenase inhibitory effect by $81.3 \pm$ $9.4 \%$, followed by the acetone extract $(50.0 \pm 10.0 \%)$, and the water extract $(16.4 \pm 1.6 \%)$ at a $500 \mathrm{~g} / \mathrm{mL}$.

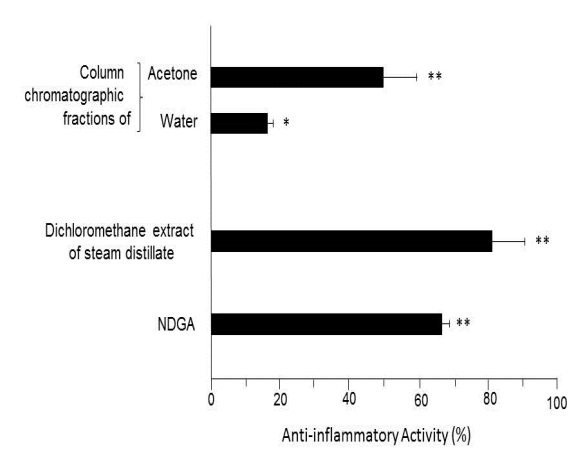

Figure 4. The results of the anti-inflammatory assay on samples prepared by steam distillation. Values are means $\pm S D(n=3) . *: p<0.05$, **: $p$ $<0.01$.

Figure 5 shows the results of the anti-inflammatory test on the samples prepared by Soxhlet extraction. Values are mean $\pm \mathrm{SD}(\mathrm{n}=3)$. A standard antioxidant, NDGA exhibited clear anti-inflammatory activity $(67.5 \pm 4.0 \%)$, indicating the method used in this study was valid. All samples tested showed dose response activity. The acetone extract showed strong anti-inflammatory activity $(70.6 \pm 18.2 \%)$ at the level of $500 \mu \mathrm{g} / \mathrm{mL}$. Extracts of hexane, chloroform, and methanol also showed appreciable anti-inflammatory activities. These results indicate that acetone extract contains strong anti-inflammatory chemicals.

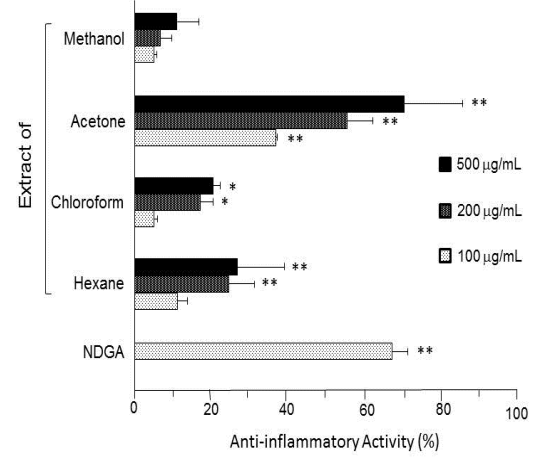

Figure 5. The results of the anti-inflammatory test on samples prepared by Soxhlet extraction. Values are means $\pm S D(n=3)$. *: $p<0.05$, **: $p$ $<$.

A previous study demonstrated that polysaccharides possessed potent anti-inflammatory activity in rats with burn injuries [26]. As mentioned above, an extract of T. versicolor, containing a polysaccharide known as PSK [16] displays some potent biological activities, including immune activity [13], antiviral activity [14], and antimetastatic activity [27]. However the precise chemical source of this mushroom's antioxidant activity is not known. Because the chemical composition of the extract is complex, choice of the extraction solvent is an important factor in obtaining target chemicals. However, the present study and previous studies mentioned above indicate that polar solvents, such as methanol, ethanol, and acetone as well as water, can isolate antioxidants from mushrooms. On the other hand, in the case of anti-inflammatory activity, a dichloromethane extract obtained from the steam distillate exhibited potent anti-inflammatory activity $(81.3 \pm 9.4 \%)$. A previous study, also found that the chloroform extract of the mushroom Agaricus blazel contained potent anti-inflammatory chemicals [28]. These results indicate that some volatile antiinflammatory chemicals are present in mushrooms.

\subsection{Chemicals Identified and Their Relationships to An- tioxidant Activity}

In the present study, among all samples examined by antioxidant assays and anti-inflammatory assay, the acetone extract exhibited the highest antioxidant activity. In the case of anti-inflammatory activity, the dichloromethane extract of the steam distillate showed the highest activity, whereas the column chromatographic acetone fraction of the residual steam distillation exhibited the second highest 
activity. These results suggest that acetone extract contains potent antioxidants as well as chemicals with antiinflammatory activity. Therefore, the acetone extract prepared by Soxhlet was analyzed by GC/MS and the results are shown in Table 1.

Table 1. Compounds identified in the acetone extract prepared by Soxhlet extraction.

\begin{tabular}{|c|c|c|}
\hline Compounds & $\mathbf{K I}^{\mathbf{a}}$ & $\begin{array}{l}\text { Amount } \\
(\mathrm{mg} / \mathrm{Kg})\end{array}$ \\
\hline \multicolumn{3}{|l|}{ Alkyl Alcohols } \\
\hline Isoamyl alcohol & 1248 & 0.02 \\
\hline 5-Hydroxy-2-pentanone & 1357 & 17.33 \\
\hline 2-Butoxyethanol & 1398 & 0.94 \\
\hline Threo-2,3-butanediol & 1530 & 0.23 \\
\hline Erythro-2,3-butanediol & 1579 & 0.13 \\
\hline 1,4-Pentaediol & 1892 & 0.15 \\
\hline 1,4-Hexanediol & 1971 & 0.10 \\
\hline 1,5-Hexanediol & 2000 & 0.05 \\
\hline Phenyl propyl alcohol & 2053 & 0.25 \\
\hline -Eudesmol & 2216 & 0.32 \\
\hline 1,4-Nonanediol & 2269 & 0.15 \\
\hline \multicolumn{3}{|l|}{ Alkyl Aldehydes and Ketones } \\
\hline 2-Methylbutanal & 910 & 0.30 \\
\hline Isovaleraldehyde & 913 & 0.47 \\
\hline Hexanal & 1073 & 0.45 \\
\hline 3-Penten-2-one & 1119 & 0.20 \\
\hline 4-Methyl-3-penten-one & 1124 & 0.44 \\
\hline 3-Hexen-2-one & 1208 & 0.03 \\
\hline 3,3-Octanedione & 1318 & 0.04 \\
\hline 6-metthyl-(E)-3-hepten-2-one & 1329 & 0.06 \\
\hline 1,4-Cyclohexanedione & 1945 & 0.11 \\
\hline \multicolumn{3}{|l|}{ Alkyl Esters and Lactones } \\
\hline -buryrolactone & 1612 & 0.51 \\
\hline -Hexalactone & 1687 & 0.05 \\
\hline -Hexalactone & 1778 & 0.20 \\
\hline -Valerolactone & 1791 & 0.34 \\
\hline 5-Hydroxy-2-hexenoic acid lactone & 1818 & 0.22 \\
\hline \multicolumn{2}{|c|}{$\begin{array}{l}\text { 3-Hydroxy-2,4,4-trimethylpentyl isobuty- } 1863 \\
\text { rate }\end{array}$} & 0.19 \\
\hline $\begin{array}{l}\text { 2,2,4-Trimetyl-1,3-pentanediol } \\
\text { monobutyrate }\end{array}$ & ${ }^{3-} 1873$ & 0.25 \\
\hline 3-Hydroxy-2-pyranone & 1980 & 0.49 \\
\hline -Nonalactone & 2016 & 0.03 \\
\hline \multirow{2}{*}{$\begin{array}{l}\text {-Hydroxy- -butyrolactone } \\
\text {-Eudesmol }\end{array}$} & 2160 & 0.62 \\
\hline & 2216 & 0.32 \\
\hline (S)-(-)- -Hydroxy- -butyrolactone & 2580 & 1.73 \\
\hline \multicolumn{3}{|l|}{ Alkyl Acids } \\
\hline Acetic acid & 1440 & 3.21 \\
\hline Formic acid & 1498 & 0.11 \\
\hline Isobutyric acid & 1560 & 0.12 \\
\hline
\end{tabular}

\begin{tabular}{|c|c|c|}
\hline 2-Propenoic acid & 1618 & 0.09 \\
\hline Valeric acid & 1712 & 0.07 \\
\hline (E)-2-Butenoic acid & 1760 & 0.11 \\
\hline Hexanoic acid & 1838 & 0.75 \\
\hline 3-Methyl-2-ovovaleric acid & 1934 & 0.09 \\
\hline Succinic anhydride & 2104 & 0.13 \\
\hline Nonanoic acid & 2154 & 0.33 \\
\hline Lactic acid & 2172 & 3.25 \\
\hline 3-Hydroxylbutyric acid & 2233 & 1.16 \\
\hline Tetradecanoic acid & 2688 & 1.74 \\
\hline Pentadecanoic acid & 2797 & 2.51 \\
\hline Hexadecanoic acid & 2811 & 18.11 \\
\hline \multicolumn{3}{|l|}{ Alkyl Esters and Acetals } \\
\hline Acetone propylene glycol acetal & 933 & 0.26 \\
\hline Acetone 2,3-bytyleneglycol acetal & 971 & 0.08 \\
\hline Acetone glycerine acetal & 1604 & 2.33 \\
\hline Diethyleneglycol monobutyl ester & 1789 & 0.67 \\
\hline \multicolumn{3}{|l|}{ Hydrocarbons } \\
\hline -Bissabolene & 1695 & 0.22 \\
\hline Nonacosan & 1898 & 0.15 \\
\hline Heneicosane & 2116 & 0.21 \\
\hline \multicolumn{3}{|l|}{ Heterocyclic Compounds } \\
\hline 2-Pentylfuran & 1222 & 0.21 \\
\hline 5-Methyl-2(H)-furanone & 1419 & 0.12 \\
\hline Furfural & 1452 & 1.48 \\
\hline Furfuryl alcohol & 1655 & 0.49 \\
\hline $2(5 \mathrm{H})$-Furanone & 1737 & 0.21 \\
\hline Acetamide & 1768 & 0.12 \\
\hline $\begin{array}{l}\text { Dihydro-3-hydroxy-4,4-diethyl-2(3H)- } \\
\text { furanone }\end{array}$ & 2021 & 0.38 \\
\hline -Butyrolactam & 2069 & 0.65 \\
\hline 5-Pentyl-2(5H)-furanone & 2098 & 0.06 \\
\hline 2-Furoic acid & 2409 & 0.34 \\
\hline 3-Hydroxypyrdine & 2417 & 0.15 \\
\hline Succinimide & 2461 & 0.09 \\
\hline $\begin{array}{l}\text { (S)-(+)-Dihydro-5-(hdroxyethyl)-2(3H)- } \\
\text { furanone }\end{array}$ & 2468 & 0.22 \\
\hline Diisobutyl phtalate & 2530 & 0.18 \\
\hline \multicolumn{3}{|l|}{ Aromatic Compounds } \\
\hline 1,2,3-Trimethylbenzene & 1267 & 0.03 \\
\hline Benzaldehhyde & 1507 & 0.15 \\
\hline o-Cresol & 1994 & 0.15 \\
\hline 2-Hydroxylacetophenone & 2134 & 0.11 \\
\hline 2-Methoxy-4-vinylphenol & 2183 & 0.49 \\
\hline Benzoic acid & 2412 & 1.31 \\
\hline Phenyl acetic acid & 2540 & 0.17 \\
\hline 2,6-dimethoxy-4-vinylphenol & 2545 & 0.33 \\
\hline
\end{tabular}

${ }^{a}$ Kovats Index on DBWAX. 
A total of 76 compounds were positively identified. They are 16 alkyl esters, acetals, and lactones $(8.29 \mathrm{mg} / \mathrm{kg}), 15$ alkyl acids (total $31.78 \mathrm{mg} / \mathrm{kg}$ ), 14 heterocyclic compounds (4.7 mg/kg), 11 alkyl alcohols $(19.67 \mathrm{mg} / \mathrm{kg}), 9$ alkyl aldehydes and ketones $(2.10 \mathrm{mg} / \mathrm{kg})$, and 8 aromatic compounds $(2.74 \mathrm{mg} / \mathrm{kg})$. Hexadecanoic acid was the largest component $(18.11 \mathrm{mg} / \mathrm{kg})$, followed by 5-hydroxy-2pentanone $(17.33 \mathrm{mg} / \mathrm{kg})$, lactic acid $(3.25 \mathrm{mg} / \mathrm{kg})$, and acetic acid $(3.21 \mathrm{mg} / \mathrm{kg})$.

The antioxidant activity of many of the constituents identified in $\mathrm{T}$. versicolor in the present study has been previously reported. The compounds with the antioxidant activity are mainly heterocyclic and aromatic compounds. Furfural $(1.48 \mathrm{mg} / \mathrm{kg})$ and furfuryl alcohol $(0.49 \mathrm{mg} / \mathrm{kg})$, which are sugar degradation products [29], inhibited aldehyde oxidation for over 40 days at the level of $500 \mu \mathrm{g} / \mathrm{mL}$ [30]. Furanones, which are formed from the Maillard reactions between carbohydrates and proteins [31] and lipids [32], are also known to have antioxidant activity [33]. Mushrooms are rich in the reactants of the Maillard reaction such as carbohydrates, proteins, and lipids [6]. Moreover, some furanones are found in fruits and their antioxidant and anti-inflammatory activities are also reported [34]. 2Methoxy-4-vinylphenol $(0.49 \mathrm{mg} / \mathrm{kg})$ and 2,6-dimetoxy-4vinylphenol $(0.33 \mathrm{mg} / \mathrm{kg})$, which are found in coffee [35], possess antioxidant activity as well as anti-inflammatory activity [36]. Phenols are well-known, naturally occurring antioxidants and are believed to be beneficial to human health [37]. A recent study has demonstrated that an ethanolic extract of white button mushroom (Agaricus bisporus) possessed potent antioxidant activity associated with its phenolic components [38]. The antioxidant and antiinflammatory activities of benzaldehyde $(0.15 \mathrm{mg} / \mathrm{kg})$ are reported and is expected to be approved for use in anticancer therapy [39]. Various $\gamma$-lactones have been known to possess antioxidant activity [40]. $\gamma$-Butyrolactone $(0.51$ $\mathrm{mg} / \mathrm{kg}$ ) showed prophylactic effects against hepatotoxicity by its anti-oxidative effect toward hepatocytes [41].

\section{Conclusion}

Traditional medicinal extract of mushroom T. versicolor is usually prepared by simply boiling the mushroom in water. Bioactive PSK was isolated only with water because it is highly water-soluble. The antioxidant activity of water extract of this mushroom was considerably lower than that of acetone extract in the present study. These results suggest that the components of the acetone extract possessing antioxidant and anti-inflammatory activities are different from PSK found in an extract of a cultured mushroom, mycelia of T. versicolor, previously. Therefore, in addition to PSK, T. versicolor contains various antioxidants and anti-inflammatory compounds, which contribute to the beneficial medicinal activities of this mushroom.

\section{References}

[1] Kalac, P. 2013. A review of chemical composition and nutritional value of wild-growing and cultivated mushrooms. J. Sci. Food Agric. 93:209-218.

[2] FAOSTAT (Food and Agriculture Organization of the United State, The Statistic Division). 2012. Edible mushroom. $\mathrm{http} / / /$ faostat.fao. org/site/567/DesktopDefaul.aspx?Page $\mathrm{ID}=567$ \#ancor.

[3] Jayakumar, T., Ramesh, E., Geraldine, P. 2006. Antioxidant activity of the oyster mushroom, Pleurotus ostreatus, on Cl4-induced liver injury in rats. Food Chem. Toxicol. 44:1989-1996.

[4] Harhaji, L., Mijatovic, S., Maksimovic-Ivanic, D., Stojanovic, I., Momcilovic, M., Maksimovic, V., Tufegdzic, S., Marjanovic, Z., Mostarica-Stojkovic, M., Vucinic, Z., Stosic-Grujicic, S. 2008. Anti-tumor effect of Coriolus versicolor methanol extract against mouse B16 melanoma cells: In vitro and in vivo study. Food Chem. Toxicol. 46, 1825-1833.

[5] Li, W.-J., Nie, S.-P., Liu, X.-Z., Zhang, H., Yang, Y., Yu, Q., Xie, M--Y., 2012. Antimicrobial properties, antioxidant activity and cytotoxicity of ethanol-soluble acidic components from Ganoderma atrum. Food Chem. Toxicol. 50, 689-694.

[6] Liu, Y.-T., Sun, J., Luo, Z.-Y., Rao, S.-Q., Su, Y.-J., Xu, R.R., Yang, Y.-J., 2012. Chemical composition of five wild edible mushrooms collected from Southwet China and their antihyperglycemic and antioxidant activity. Food Chem. Toxicol. 50, 1238-1244.

[7] öztürk, M., Duru, M.E., Kivrak, S., Mercan-Dogan, N., Türkoglu, A., özler, M.A., 2011. In vitro antioxidant, anticholinesterase and antimicrobial activity studies on three Agaricus species with fatty acid compositions and iron contents: A comparative study on the three most edible mushrooms. Food Chem. Toxicol. 49, 1353-1360.

[8] Takeda, K., Okumura, K., 2004. CAM and NK cells. ECAM 1, 17-27.

[9] Sugui, M.M., Alves de Lima, P.L., Delmanto, R.D., da Eira, A.F., Salvadori, D.M.F., Ribeiro, L.R., 2003. Antimutagenic effect of Lentimula edodes (BERK.) Pegler musroom and possible variation among lineages. Food Chem. Toxicol. 41, $555-560$.

[10] Barros, L., Cruz, T. Baptista, P., Estevinho, L.M., Ferreira, I.C.F.R., 2008. Wild and commercial mushrooms as source of nutrients and nutraceuticals. Food Chem. Toxicol. 46, $2742-2747$.

[11] Rubel, W., Arora, D., 2008. A study of cultural bias in field guide determinations of mushroom edibility using the iconic mushroom, Amanita muscaria, as an example. Econ. Bot. 62, 223-243.

[12] Li, F., Wen, H., Zhang, Y., Aa, M., Liu, X., 2011. Purification and characterization of a novel immunomodulatory protein from the medicinal mushroom Trametes versicolor. Sci. China Life Sci. 54, 379-85.

[13] Standish, L.J., Wenner, C.A., Sweet, E.S., Bridge, C., Nelson, A., Martzen, M., Novack, J., Torkelson, C., 2008. Trametes versicolor mushroom immune therapy in breast cancer. J. Soc. Integr. Oncol. 6, 122-128.

[14] Teplyakova, T.V., Psurtseva, N.V., Kosogova, T.A., Mazurkova, N.A., Khanin, V.A., Vlasenko, V.A., 2012. Antiviral activity of polyporoid mushrooms (higher Basidiomycetes) 
from Altai Mountains (Russia). Intern. J. Med. Mushrooms $14,37-45$.

[15] Fisher, M., Yang, L.X., 2002. Anticancer effects and mechanisms of polysaccharide-K (PSK): implications of cancer immunotherapy. Anticancer Res. 22, 1737-1754.

[16] Tsukagoshi, S., Hashimoto, Y., Fujii, G., Kobayashi, H., Nomoto, K., Orita, K., 1984. Krestin (PSK). Cancer Treat. Rev. 11, 131-55.

[17] Moon, J.-K., Shibamoto, T., 2009. Antioxidant assays for plant and food components. J. Agric. Food Chem. 57, 16551666.

[18] Uttara, B., Singh, A.V., Zamboni, P., Mahajan, R.T., 2009. Oxidative stress and neurodegenerative diseases: a review of upstream and downstream antioxidant therapeutic options. Curr. Neuropharmacol. 7, 65-74.

[19] Kamiyama, M., Kishimoto, Y., Tani, M., Andoh, K., Utsunomiya, K., Kondo, K., 2009. Inhibition of low-density lipoprotein oxidation by Nagano purple grape (Vitis viniferaxVitis labrusca). J. Nutr. Sci. Vitaminol. 55, 471-8.

[20] Sone, Y., Moon, J.K., Mai, T.T., Thu, N.N., Asano, E., Yamaguchi, K., Otsuka, Y., Shibamoto, T., 2011. Antioxidant/anti-inflammatory activities and total phenolic content of extracts obtained from plants grown in Vietnam. J. Sci. Food Agric. 91, 2259-2264.

[21] Nam, S., Jang, H.-W., Shibamoto, T., 2012. Antioxidant activities of extract from teas prepared from medicinal plants, Morus alba L., Camellia sinensis L., and Cudrania tricuspidata, and their volatile components. J. Agric. Food Chem. 60, 9097-9105.

[22] Mau, J.-L., Chao, G.-R., Wu, K.-T., 2001. Antioxidant properties of methanolic extracts from several ear mushrooms. J. Agric. Food Chem. 49, 5461-5467.

[23] Yang, Y., Hu, J., Liu, Y., Feng, N., Chen, H., Tang, Q., Ye, L., Zhang, J., 2011. Antioxidant and cytotoxic activities of ethanolic extracts and isolated fractions of species of the genus Phellinus Quél. (Aphyllophoromycetideas). Int. J. Med. Mushrooms 13, 145-152.

[24] Li, B., Lu, F., Suo, X., Nan, H., Li, B., 2010. Antioxidant properties of cap and stipe from Coprinus comatus. Molecules $15,1473-1486$.

[25] Sun, J., He, H., Xie, B.J., 2004. Novel antioxidant peptides from fermented mushroom Ganoderma lucidum. J. Agric. Food Chem. 52, 6646-6652.

[26] Wu, D.M., Duan, W.Q., Liu, Y., Cen, Y., 2010. Antiinflammatory effect of the polysaccharides of golden needle mushroom in burned rats. Int. J. Biol. Macromol. 46, 100 103.

[27] Kobayashi, H., Matsunaga, K., Oguchi, Y., 1995. Antimetastatic effects of PSK (Krestin), a protein-bound polysaccharide obtained from basidiomycetes: an overview. Cancer epidemiology, biomarkers \& prevention : a publication of the American Association for Cancer Research, cosponsored by the American Society of Preventive Oncology 4, 275-81.

[28] Song, H.H., Chae, H.S., Oh, S.R., Lee, H.K., Chin, Y.W.,
2012. Anti-inflammatory and anti-allergic effect of Agaricus blazei extract in bone marrow-derived mast cells. Am. J. Chin. Med. 40, 1073-1084.

[29] Hodge, J., 1967. Origin of flavor in foods nonenzymatic browning reactions. In: Schultz, H.W., Day, E.A., Libbey, L.M. (Eds). Chemistry and Physiology of Flavors. AVI Pub. Co., Westport, pp. 465-491.

[30] Yanagimoto, K., Lee, K.-G., Ochi, H., Shibamoto, T., 2002. Antioxidative Activity of Heterocyclic Compounds Found in Coffee Volatiles Produced by Maillard Reaction. J. Agric.Food Chem. 50, 5480-5484.

[31] Colin Slaughter, J., 1999. The naturally occurring furanones: formation and function from pheromone to food. Biol. Rev. Camb. Philos. Soc. 74, 259-276.

[32] Ohnishi, S., Shibamoto, T., 1984. Volatile compounds from heated beef fat and beef fat with glycine. J. Agric. Food Chem. 32, 987-992.

[33] Miyake, T., Shibamoto, T., 1998. Inhibition of malonaldehyde and acetaldehyde formation from blood plasma oxidation by naturally occurring antioxidants. J. Agric. Food Chem. 46, 3694-3697.

[34] Weber, V., Coudert, P., Rubat, C., Duroux, E., Vallee-Goyet, D., Gardette, D., Bria, M., Albuisson, E., Leal, F., Gramain, J. C., Couquelet, J., Madesclaire, M., 2002. Novel 4,5diaryl-3-hydroxy-2 $(5 \mathrm{H})$-furanones as anti-oxidants and antiinflammatory agents. Bioorg. Med. Chem. 10, 1647-1658.

[35] Flament, I., Bessiere-Thomas, Y., 2002. Coffee Flavor Chemistry. John Wiley \& Sons, Ltd.: New York.

[36] Tabaraki R,, Yosefi Z., Ali H., 2012. Asadi Gharneh, Chemical composition and antioxidant properties of Malva sylvestris L. J. Res. Agric. Sci. 8, 59-68.

[37] Wu, D.M., Duan, W.Q., Liu, Y., Cen, Y., 2010. Antiinflammatory effect of the polysaccharides of golden needle mushroom in burned rats. 46, 100-103.

[38] Hu, M.L., 2011. Dietary polyphenols as antioxidants and anticancer agents: more questions than answers. Chang Gung Med. J. 34, 449-460.

[39] Liu, J., Jia, L., Kan, J., Jin, C.-h., 2013. In vitro and in vivo antioxidant activity of ethanolic extract of white button mushroom (Agaricus bisporus). Food Chem. Toxicol. 51, 310316.

[40] Tan Nhut Doan, D.T.T., 2011. Synthesis, antioxidant and antimicrobial activities of a novel series of chalcones, pyrazolic chalcones, and allylic chalcones. Pharmacol. Pharm. 2, 282-288.

[41] Kaur, P., Das, P., Chaudhary, A., Singh, B., 2012. Naturally occurring limonene to cinnamyl-type gamma-butyrolactone substituted aldol condensation derivatives as antioxidant compounds. Nat. Prod. Commun. 7, 1127-11130.

[42] Khadeer Ahamed, M.B., Krishna, V., Dandin, C.J., 2010. In vitro antioxidant and in vivo prophylactic effects of two gamma-lactones isolated from Grewia tiliaefolia against hepatotoxicity in carbon tetrachloride intoxicated rats. Eur. J. Pharmacol. 631, 42-52. 